\title{
A produção do "patrimônio revitalizado" pelo Porto Maravilha: categorizações e gestões de uso em uma rua comercial
}

The production of "revitalized heritage" by Porto Maravilha. Categorizations and use managements in a commercial street

\section{Roberta Sampaio Guimarães}

Brasil. Universidade do Estado do Rio de Janeiro. Professora do Departamento de Antropologia e do Programa de Pós-Graduação em Ciências Sociais da Universidade do Estado do Rio de Janeiro (UERJ).ID ORCID: http://orcid.org/0000-0003-3393-4398.E-mail:guimaraes_45@yahoo.com.br.

\section{Resumo}

Neste artigo analiso a produção de políticas patrimoniais associadas a projetos de urbanização focalizando os atos estatais de reordenamento da região portuária do Rio de Janeiro. Inicialmente, apresento entrevistas com agentes governamentais, materiais informativos e de propaganda, estudos técnicos e reportagens jornalísticas para abordar como as recentes transformações dessa região foram produzidas desde a década de1980 por meio de legislações e categorizações que autorizaram e legitimaram amplas intervenções públicas e privadas. Em seguida, utilizo principalmente registros fotográficos e conversas informais com comerciantes realizadas durante a operação urbana Porto Maravilha (2009-2016) para refletir sobre a execução de procedimentos rotineiros de gestão e fiscalização visando constranger usos e materialidades considerados inadequados. Para pensar os mecanismos de produção do Porto Maravilha e seus efeitos no cotidiano dos comerciantes, proponho a ideia de "patrimônio revitalizado", que busca realçar a complementaridade entre as dinâmicas de patrimonialização e de reurbanização. Com isso, pretendo questionar as visões românticas que tendem a opor ontologicamente as políticas de revitalização urbana às políticas de preservação patrimonial, como se as primeiras fossem relacionadas aos interesses dos mercados 
imobiliário e financeiro e as segundas exclusivamente constituídas por iniciativas de valorização de identidades "autênticas e singulares". Em contraposição a essa suposta dicotomia, sugiro que no contexto contemporâneo de implementação de políticas urbanas neoliberais, as propostas de "patrimônio revitalizado" têm como resultado a mercantilização da cidade por meio do aumento do controle sobre os espaços e as práticas de seus habitantes.

Palavras-chave: Políticas Patrimoniais, Projetos Urbanísticos, Atos do Estado, Porto Maravilha, Rio de Janeiro.

\section{Abstract}

In this article I analyze the production of heritage policies associated to urbanization projects focusing on state acts of reordering Rio de Janeiro's port region. Initially, I present interviews with government agents, information and propaganda materials, technical studies and journalistic reports to discuss how the recent transformations of this region have been produced since the $1980 \mathrm{~s}$ through legislation and categorizations that authorized and legitimized broad public and private interventions. Then, I use mainly photographic records and informal conversations with merchants held during urban operation Porto Maravilha (2009-2016) to reflect on the implementation of routine management and inspection procedures to constrain uses and materiality considered inadequate. In order to ponder the production mechanisms of Porto Maravilha and their effect on the daily life of merchants, I propose the idea of "revitalized heritage", which seeks to highlight the complementarity between the dynamics of patrimonialisation and urbanization. With this, I intend to question the romantic visions that tend to ontologically oppose the policies of urban revitalization to patrimonial preservation policies, as if the former were related to the interests of the real estate and financial markets and the latter exclusively constituted by initiatives for the valorization of "authentic and unique" identities. In contrast to this supposed dichotomy, I suggest that in the contemporary context of the implementation of neoliberal urban policies, proposals for "revitalized heritage" result in the commercialization of the city by increasing control over spaces and practices of its inhabitants.

Keywords: Heritage Policies, Urban Projects, Acts of the State, Porto Maravilha, Rio de Janeiro. 


\section{A PRODUÇÃO DO “PATRIMÔNIO REVITALIZADO” PELO PORTO MARAVILHA: CATEGORIZAÇÕES E GESTÕES DE USO EM UMA RUA COMERCIAL' ${ }^{1}$}

Faz cinquenta anos que as políticas de preservação patrimonial brasileiras se ocupam com os grandes centros urbanos. O gradual processo de redemocratização iniciado em 1979 teve importante papel na inflexão das políticas implementadas pelo Instituto do Patrimônio Histórico e Artístico Nacional (Iphan), que desde sua fundação no Estado Novo voltava-se para a preservação de construções consideradas de excepcional valor histórico e cultural, como igrejas católicas, fortificações militares e edificações de estilo arquitetônico consagrados. Com a reabertura política do país, fortaleceu-se no instituto a corrente de pensamento que percebia a nação como heterogênea e culturalmente diversa e que acreditava na possibilidade de resistir ao processo homogeneizante da indústria cultural através da proteção de bens associados à "autêntica cultura popular" (GONÇALVES, 1996). Para operacionalizar a representação da diversidade cultural, uma das medidas foi descentralizar o processo de seleção e preservação de bens, incentivando a criação de órgãos patrimoniais estaduais e municipais, possibilitando que novas identificações fossem feitas por movimentos sociais, organizações não-governamentais e empresas privadas (FONSECA, 2005).

Nesse momento, conjuntos de casas e prédios passaram a ser percebidos como testemunhos valiosos do ambiente social das cidades e de seus habitantes. Em cidades de grande porte e acelerado crescimento, as políticas patrimoniais foram também associadas à elaboração de "projetos urbanos", noção que portava uma crítica à produção arquitetônica modernista e ao urbanismo funcionalista em voga no mundo desde a década de 1950 (JACOBS, 2007; GORELICK, 2005), abarcando propostas de requalificação do espaço público, reabilitação de conjuntos arquitetônicos e criação de novas centralidades

Artigo produzido no âmbito dos projetos de pesquisa "As mediações de arquitetos e urbanistas na patrimonialização de espaços da Zona Portuária carioca" (Faperj, 2014-2015) e "As mediações de arquitetos e urbanistas nos processos de patrimonialização da cidade do Rio de Janeiro" (bolsa JCNE-Faperj, 20182021; Prociência-UERJ/Faperj, 2018-2021). 
(BARANDIER, 2006). Essas propostas iam ao encontro de orientações internacionais voltadas para a valorização das "obras modestas" e de conjuntos urbanos, como a Carta de Veneza (1964), a Declaração de Amsterdã (1975) e a Convenção de Nairobi (1976), que afirmavam a necessidade de preservar conjuntos arquitetônicos de forma integrada ao planejamento urbano e regional e considerando os critérios afetivos de seus habitantes.

Os "sítios históricos urbanos" brasileiros receberam então especial atenção dos recém-criados órgãos patrimoniais regionais através da identificação de espaços e de regulamentações sobre as formas de ocupação do solo e dos usos que seriam mais adequados à preservação. Contudo, a expansão de uma política urbana de viés neoliberal com forte presença do mercado financeiro redesenhou as políticas governamentais de forma atrelada a fluxos internacionais de capitais. Assim, se nos discursos governamentais de criação de tais sítios históricos houve uma tendência a colocar o patrimônio como antagônico às investidas do mercado imobiliário, na prática o que se viu foram formas combinadas de ação, gestão e investimento dos setores públicos e privados, com as políticas patrimoniais criando ou reforçando nichos de exploração econômica e de atuação do turismo cultural.

Neste artigo analiso os processos de produção desse "patrimônio" associado a projetos de "revitalização" focalizando particularmente os atos estatais direcionados ao reordenamento da região portuária do Rio de Janeiro. Entendo aqui como atos estatais os "atos autorizados, dotados de uma autoridade que, gradualmente, por uma série de delegações em cadeia, remete a um lugar último: o Estado" (BOURDIEU, 2012, p. 40). Assim, além de afirmar que as intervenções em áreas urbanas fazem parte da competição internacional pela atração de capitais, mão de obra especializada e grandes eventos, busco refletir sobre os mecanismos e atos rotineiros de gestão que são acionados para realizá-las e geri-las.

Inicialmente, apresento entrevistas com agentes governamentais, materiais informativos e de propaganda, estudos técnicos e reportagens jornalísticas para abordar como as recentes transformações dessa região foram produzidas desde a década de 1980 por meio de legislações e categorizações 
que autorizaram e legitimaram amplas intervenções públicas e privadas. Em seguida, utilizo principalmente registros fotográficos e conversas informais com comerciantes realizadas durante a operação urbana Porto Maravilha (2009-2016) para refletir sobre a execução de procedimentos rotineiros de gestão e fiscalização visando constranger usos e materialidades considerados inadequados.

Para pensar os mecanismos de produção do Porto Maravilha e seus efeitos no cotidiano dos comerciantes, proponho a ideia de "patrimônio revitalizado", que busca realçar a complementaridade entre as dinâmicas de patrimonialização e de reurbanização. Com isso, pretendo questionar as visões românticas que tendem a opor ontologicamente as políticas de revitalização urbana às políticas de preservação patrimonial, como se as primeiras fossem relacionadas aos interesses dos mercados imobiliários e financeiros e as segundas exclusivamente constituídas por iniciativas de valorização de identidades "autênticas e singulares". Em contraposição a essa suposta dicotomia, sugiro que, no contexto contemporâneo de implementação de políticas urbanas neoliberais, as propostas de "patrimônio revitalizado" têm como resultado a mercantilização da cidade por meio do aumento do controle sobre os espaços e as práticas de seus habitantes.

\section{A CONJUGAÇÃO DE POLÍTICAS PATRIMONIAIS E DE URBANIZAÇÃO NO RIO DE JANEIRO}

As intervenções combinadas de patrimonialização e revitalização urbana foram experimentadas de forma pioneira no Rio de Janeiro a partir de 1979, através da elaboração e regulamentação do Corredor Cultural do Centro, política de escopo municipal que alterou o status legal de cerca de 1.300 bens localizados da região central da cidade ${ }^{2}$. Políticas governamentais semelhantes foram nos anos seguintes implementadas também em outras capitais brasileiras, como

A área preservada abrangeu Lapa, Passeio Público, Cinelândia, Carioca, Praça Tiradentes, Largo de São Francisco, Saara e Praça XV. 
Salvador, Recife, Fortaleza, São Paulo, Porto Alegre e Belém, confirmando a tendência a uma adesão nacional aos "projetos urbanos".

Retoricamente, o projeto do Corredor Cultural do Centro foi apresentado como contraposição ao urbanismo praticado durante a década de 1960 na região, que havia demolido lojas populares comandadas por mulçumanos, cristão-maronitas e judeus para permitir o alargamento de vias de tráfego e a expansão da área de negócios ${ }^{3}$. Como informado por um dos principais articuladores do Corredor Cultural do Centro, o intuito era preservar não só os imóveis que "testemunhavam" materialmente o passado histórico da cidade, mas também as pessoas que neles habitavam, impedindo que se impusessem novas dinâmicas de ocupação urbana (planejador urbano Augusto Ivan Pinheiro, entrevistado em 30 ago. 2008). As concepções do projeto haviam se calcado, assim, na percepção subjetiva, mas nada garantida, de que a manutenção material de casas e ruas seria um suporte de permanência das identidades coletivas e individuais frente às inconstâncias da vida social.

Seguindo as orientações internacionais de integrar o patrimônio ao planejamento das cidades, outras iniciativas governamentais foram implementadas durante o processo de construção do Corredor Cultural do Centro. Entre elas, o restauro do Paço Imperial pelo Iphan entre 1982 e 1985, que o transformou em museu dotado de livraria e café e propulsionou a "revitalização" de todo entorno da Praça XV, localidade que remetia ao passado imperial da cidade $^{4}$. Como narrado pelo arquiteto responsável pelo restauro e na época diretor da Regional do Rio de Janeiro do Iphan, o objetivo da intervenção era potencializar economicamente a região, incentivar o turismo e produzir seu reordenamento urbano, com a justificativa de que só assim os bens patrimoniais podiam ser conservados. Para tanto, foram realizadas ações em conjunto

\footnotetext{
A ideia era evitar a implantação de projetos como o prolongamento das avenidas República do Paraguai e Chile, que levaria à desapropriação de vários imóveis da Sociedade dos Amigos das Adjacências da Rua da Alfândega (Saara), cujas lojas populares se estendiam pelas ruas dos Andradas, Buenos Aires, Alfândega, Senhor dos Passos, Uruguaiana, entre outras (PIO, 2001).

4 No Brasil Imperial, a Praça XV era envolta pelas edificações do Paço Imperial (que abrigava os membros da família Real), da Igreja, do centro comercial e da Alfândega, representando a concentração de poder institucional típica da ocupação urbana latino-americana, com as edificações do Estado, da Igreja e do mercado pouco distinguindo-se espacialmente (HOLSTON, 1993, p. 118).
} 
com a Prefeitura de extinguir o antigo mercado de peixes que havia na praça e de deslocar os terminais de ônibus dali (arquiteto Glauco Campello, entrevistado em 11 nov. 2008).

A criação do Corredor Cultural do Centro, portanto, não havia significado apenas a superação de um modelo rodoviarista em prol dos vínculos afetivos dos habitantes dos bairros centrais. Com ele ocorreu também uma nova forma de gestão sobre os espaços da cidade, calcado em um modelo que unia os ideais humanistas do patrimônio, o reordenamento urbano autoritário e interesses imobiliários e turísticos. Esse modelo de "patrimônio revitalizado" foi logo em seguida implementado na região portuária, através do projeto Sagas, acrônimo dos bairros de Saúde, Gamboa e Santo Cristo. Elaborado entre 1983 e 1988, o Sagas preservou cerca de 1.100 bens, incluindo imóveis coloniais, cortiços da época do Império, igrejas católicas e murais de botecos portugueses ${ }^{5}$.

Assim como nas localidades de atuação do Corredor Cultural do Centro, os bairros portuários eram predominantemente habitados por camadas populares e pelo pequeno comércio, consideradas componentes do "núcleo histórico" da cidade. Da mesma forma, a delimitação do Sagas contou com a mobilização de associações de moradores, movimentos sociais e órgãos governamentais, sendo discursivamente construída como contraponto a um tipo de crescimento urbano percebido como prejudicial à "qualidade de vida", como explicita a fala de um arquiteto que no período era técnico do Instituto Estadual de Patrimônio Cultural. Para ele, a legislação urbanística era aliada à mercantilização da região, enquanto a ação patrimonial atuaria em prol da população local e das atividades residenciais ao restringir os usos tidos como sujos e inadequados dos depósitos, oficinas, frigoríficos e garagens (arquiteto Luiz Eduardo Pinheiro, entrevistado em 15 set. 2003).

Contudo, se a legislação do Corredor Cultural do Centro havia instituído apenas duas categorias de edificações, as "protegidas" (consideradas importantes do ponto de vista histórico e paisagístico) e as "renováveis" (passíveis de serem reformadas, demolidas ou reconstruídas), a legislação que regulamentou

Dados apresentados no “Guia das Apacs” (PREFEITURA DA CIDADE DO RIO DE JANEIRO, 2012). 
o Sagas previu três figuras de proteção. Os bens "tombados" não poderiam ser demolidos nem sofrer alterações que os descaracterizassem, fosse na parte externa ou interna do imóvel. Já os "preservados" não poderiam ser demolidos nem sofrer alteração nas características originais de fachada, telhado ou volumetria, sendo permitida a realização de obras no seu interior, desde que seguissem as condições pré-estabelecidas pelo órgão patrimonial regulador. $\mathrm{E}$ os "tutelados" poderiam ser modificados ou demolidos, mas estavam sujeitos a restrições do órgão patrimonial, como seguir as características e o gabarito dos prédios vizinhos que fossem tombados ou preservados ${ }^{6}$.

Os morros portuários da Conceição, da Saúde, do Livramento e da Gamboa foram então tutelados pelo Sagas, com algumas edificações pontuais recebendo ações de preservação ou tombamento. Já os morros da Providência, do Pinto e de São Diogo ficaram com suas partes médias e altas excluídas da proteção, embora suas bases tenham sido tuteladas. Nas áreas planas localizadas entre esses morros, foram tuteladas somente as de ocupação anterior ao século XX, também com algumas preservações e tombamentos pontuais de sobrados. Ficou assim fora da proteção patrimonial toda a área aterrada da orla no início do século, onde havia sido construída a infraestrutura portuária contendo armazéns, galpões e linhas férreas. Foi ainda completamente ignorado pela patrimonialização o bairro portuário do Caju.

\section{DA CATEGORIZAÇÃO PATRIMONIAL À “REVITALIZAÇÃO” DA REGIÃO PORTUÁRIA}

A criação do Sagas, portanto, mobilizou o sentimento de preservação da memória afetiva dos habitantes e também discursos que afirmavam um suposto processo de "deterioração e ocupação irregular ou indevida" dos imóveis.

\footnotetext{
Após a experiência do Sagas, a política de proteção de amplos conjuntos urbanos se consolidou juridicamente através de decreto municipal de 1988, que definiu os parâmetros legais do que se denominou Área de Proteção Ambiental (Apa). Foram a partir de então consideradas áreas passíveis de proteção as que apresentassem "características notáveis nos aspectos naturais ou culturais", sendo estes últimos traduzidos em "inequívoco valor afetivo coletivo ou em marco na história da comunidade” (CARLOS, 2008, p. 100-101).
} 
Consequentemente, ofereceram base retórica para a implementação de medidas de conservação de seus aspectos físicos e de transformação de seus usos. Assim, logo após a patrimonialização, foram desenvolvidas nessas localidades múltiplas formas de governar baseadas na autoridade estatal, já legitimadas pela definição do que seria "cultural" (e em contraposição ao que poderia ser descartado ou vendido) e também de quais práticas passariam a ser consideradas "legais" (e quais seriam tornadas ilegais).

A "revitalização" da região começou a ser concebida já durante as gestões municipais de César Maia (PMDB/PFL, 1993-1996) e de Luiz Paulo Conde (PFL, 1997-2000), através de estudos, legislações, discursos e ações pontuais que visavam torná-la economicamente interessante a investidores públicos e privados. Entre essas ações, a vinda ao Brasil de consultores catalães após a realização dos Jogos Olímpicos de Barcelona de 1992; a aprovação da Lei de Modernização dos Portos em 1993, que deu início às articulações entre ministérios, autarquias e bancos federais; e estudos de experiências internacionais de revitalização de áreas portuárias como Genova, Porto, Barcelona, Baltimore, Manchester e Londres, realizados pela Prefeitura em busca de um modelo de "desenvolvimento" e "inserção econômica" dos bairros portuários?.

Nesse mesmo período, a gestão municipal encampou um discurso de combate à "desordem urbana" apoiado no emergente imaginário que representava a cidade como violenta, territorialmente partida entre "favela e asfalto" e moralmente oposta entre "marginalizados e civilizados" (LEITE, 1995; PACHECO DE OLIVEIRA, 2014) $)^{8}$. Espaços e habitantes da região portuária passaram a ser associados também à desordem e violência urbanas. Houve uma notória mudança discursiva: se antes os bairros eram representados como

\footnotetext{
Segundo Alexandre Mendes Nazareth, então diretor do Departamento Geral de Patrimônio Cultural (DGPC), órgão patrimonial municipal, esses estudos seriam "o início de abrangentes projetos para a revitalização de suas áreas degradadas [referindo-se aos bairros portuários cariocas], [...] com intuito de encontrar uma adequada forma para o desenvolvimento desses bairros e sua melhor inserção à vida econômica e sociocultural do centro da cidade" (NAZARETH, 1994, p. 4).

8 Esse imaginário foi produzido e difundido por reportagens jornalísticas cotidianas e diferentes produtos mediadores, como o livro-reportagem Cidade partida, de Zuenir Ventura (1994), os filmes Notícias de uma guerra particular, de Katia Lund e João Moreira Salles (1999), e Orfeu, de Cacá Diegues (1999), e o romance Cidade de Deus, de Paulo Lins (2001).
} 
locais de moradia e da "autêntica cultura popular", depois foram ressignificados como espaços de "prostituição, mendicância, tráfico de drogas e favelas".

Gradualmente, o valor patrimonial da região foi atribuído pela Prefeitura somente aos aspectos físicos dos imóveis que remeteriam ao passado colonial, apesar de seu estado de "abandono e degradação" em função dos maus usos que habitantes "violentos, amorais e contingenciais" impunham ao lugar. Dessa forma, foi posto em marcha o projeto de revitalização da região, tanto em nome de um "patrimônio cultural" que estaria na iminência de ser perdido, quanto da suposta necessidade de "integração/ordem urbana”. As classificações espaciais criadas pelo Sagas passaram a ser utilizadas para segmentar diferentes modalidades de intervenção, fazendo com que a política patrimonial operasse não apenas na identificação de valores culturais, mas na remodelação do mundo social. Enquanto relato fundador de espaços, a legislação patrimonial teve, portanto, "poder distributivo e força performativa" (CERTEAU, 2011, p. 191).

Como desdobramento, os "morros históricos" preservados pelo Sagas receberam incentivos ao turismo e à atração residencial da classe média, através de ações de recuperação física de casas e sobrados e da identificação de espaços "vazios" $\mathrm{e}$ "imóveis arruinados" ${ }^{10}$. Nas áreas planas tuteladas foram ainda acionados mecanismos de disciplinamento de usos, como retirada de moradias construídas debaixo de viadutos, criação ou reforma de praças e largos e restrição a vendedores ambulantes.

Os efeitos do Sagas podem ser mais bem compreendidos quando observadas também as políticas idealizadas para alguns dos espaços contíguos a esses morros que foram excluídos da proteção patrimonial. No morro da

\footnotetext{
9 Entre as medidas voltadas para novas construções habitacionais, destacou-se o projeto Habitacional da Saúde (1996-2001), desenvolvido pela Prefeitura em parceria com a Caixa Econômica Federal. Em sua maior parte, suas unidades habitacionais foram ocupadas por funcionários públicos com renda familiar em torno de dez salários mínimo. Entre 1998 e 2000, o Morro da Conceição recebeu também o ProRio-Programa de Recuperação Orientada, conjunto de estudos e ações patrimoniais, arquitetônicos e urbanísticos elaborado pela Prefeitura em associação com o governo francês.

${ }_{10}$ Entre 1996 e 1998, a Prefeitura realizou o projeto Reabilitação de Cortiços, cujos alvos foram imóveis que poderiam ser usados como habitação coletiva, com cômodos que variavam entre $11 \mathrm{~m}^{2}$ e $20 \mathrm{~m}^{2} \mathrm{e}$ banheiros e cozinhas de uso comum. A continuação do projeto recebeu o apoio da Caixa Econômica Federal, que no ano 2000 criou o Programa de Reabilitação de Sítios Históricos buscando a reinserção do uso habitacional nos centros das cidades brasileiras.
} 
Providência e no bairro do Caju foi executado o programa Favela-Bairro, que, por meio da implementação de infraestrutura urbana, serviços, equipamentos públicos e políticas sociais, buscou controlar as áreas "perigosas e marginalizadas" da região. Já a extensa orla onde ficavam localizados os galpões, armazéns e ramais ferroviários pertencentes à retro área portuária foi taxada como um grande "vazio ocupacional", desconsiderando as atividades que eram ali desenvolvidas, como os depósitos informais de mercadorias do comércio ambulante e as oficinas de confecção de produtos carnavalescos. A partir de parcerias entre o poder público e a iniciativa privada, toda a área foi disponibilizada para o mercado imobiliário e para a possibilidade de empresas explorarem novos equipamentos urbanos e culturais que fossem por ela financiados (COMPANS, 1998).

Ou seja, ao reordenar simbolicamente as classificações dos imóveis e logradouros da região, o Sagas também definiu quais seriam as modalidades de intervenção. Operando distinções entre o que seria supostamente "histórico e cultural" e o que não, esse ato estatal indicou o que era inalienável e o que, em contrapartida, poderia ser mercantilizado. A noção de patrimônio cultural engendrou, portanto, um jogo dialético entre preservação e disponibilização de bens (WEINER, 1992), estruturando a percepção de que alguns espaços e habitantes seriam parte da herança da cidade e deveriam ser preservados, enquanto outros seriam supostamente inautênticos, degradantes e contingenciais, podendo ser trocados, extintos, vendidos: ou "revitalizados".

\section{O PAPEL DO PATRIMÔNIO NA PARCERIA PÚBLICO-PRIVADO DO PORTO MARAVILHA}

No avançar do teatro de ações, a Prefeitura criou em 1998 o Instituto Pereira Passos ${ }^{11}$, que assumiu o processo de transformação urbanística da

11 Em seu nome, o instituto homenageava o engenheiro civil e prefeito da cidade que realizou diversas obras nos bairros portuários e do Centro entre 1903 e 1906 e que ficaram conhecidas como Reforma Pereira Passos. Suas ações "modernizadoras, embelezadoras e saneadoras” encampou a demolição de inúmeros cortiços, a construção do "porto moderno" e a vacinação compulsória da população, sendo apontada 
região. Com a reeleição e início da dupla gestão do prefeito César Maia (PTB/ PFL/DEM, 2001-2008) foi divulgado o Porto do Rio - Plano de Recuperação e Revitalização da Região Portuária do Rio de Janeiro (2001). Além da reestruturação de ruas e logradouros, a Prefeitura construiu o centro poliesportivo Vila Olímpica (2005) e o centro de produção de desfiles carnavalescos Cidade do Samba (2006), ambos no bairro da Gamboa. O principal projeto idealizado para catalisar a transformação da região em polo turístico, no entanto, fracassou: a construção na Praça Mauá de uma filial do Museu Guggenheim ${ }^{12}$.

Como aponta Sarue (2016), foi da confluência de interesses com o governo federal de Luiz Inácio Lula da Silva (PT, 2003-2010) em sediar os Jogos Olímpicos que se criou dentro do Ministério das Cidades o Grupo Executivo Interministerial da Área Portuária do Rio de Janeiro (2004-2006), liderado pelo Ministério do Planejamento e pela Superintendência do Patrimônio da União. O plano Porto do Rio passou por uma reformulação, especialmente em relação ao rearranjo institucional e financeiro do projeto e à adoção de instrumentos de política urbana previstos no Estatuto da Cidade.

Uma nova etapa do processo de transformação urbanística foi alcançada a partir de 2006, quando foi decretada pelo prefeito a Área de Especial Interesse Urbanístico da Região Portuária. Essa área possibilitava a formação de parcerias com o setor privado e institucionalizava sua influência na formulação da política, regulamentando o recebimento de propostas e estudos realizados por este setor para viabilizar sua participação em uma concessão ou parceria público-privada a partir das manifestações de interesse público. O decreto estabeleceu ainda a formação de um grupo de trabalho para coordenar os estudos, com a participação da Prefeitura e a convocação das empresas responsáveis pelo estudo vencedor, no caso, o consórcio Rio Mar e Vila.

por diversos autores como uma reforma desejosa de higienizar física e moralmente espaços e habitantes (CARVALHO, 2001; CHALLOUB, 1996).

12 A Fundação Guggenheim era nova-iorquina e tinha prestígio internacional por causa de sua presença em cidades como Bilbao, Berlim e Veneza. O contrato entre ela e a Prefeitura teve seus valores contestados por vereadores e seus princípios construtivos e expositivos criticados por diversos arquitetos e gestores museais, que acusavam o "caráter shopping center" do projeto, já que previa a instalação de centros comerciais e estacionamento. 
O projeto político de reurbanizar o porto carioca se concretizou a partir de 2009, quando foi sancionada no início da dupla gestão do prefeito Eduardo Paes (PMDB, 2009-2016) a Operação Urbana Consorciada da Área de Especial Interesse Urbanístico da Região Portuária do Rio de Janeiro. Batizada como Porto Maravilha, tais intervenções foram implementadas e geridas pela Companhia de Desenvolvimento Urbano da Região do Porto do Rio de Janeiro (Cdurp), sociedade de economia mista que contratou em 2011 a Concessionária Porto Novo para executar obras e prestar serviços públicos municipais na região até 2026, na maior parceria público-privada realizada até então no país ${ }^{13}$. A concessionária foi composta pelas mesmas empresas do consórcio Rio Mar e Vila.

Com o alinhamento dos governos federal, estadual e municipal, o Porto Maravilha recebeu vultosos recursos financeiros para projetos de melhoria de infraestrutura urbana, mobilidade, segurança pública e patrimônio atrelados retoricamente à realização da Copa do Mundo de 2014 e dos Jogos Olímpicos de 2016. A proposta era estimular o turismo nacional e internacional, a instalação de empresas multinacionais e a ocupação habitacional de classe média na região. No bojo dos investimentos em infraestrutura, diversas operações imobiliárias foram realizadas e vários equipamentos culturais e de entretenimento inaugurados.

Os locais tidos como favelizados ou perigosos receberam políticas de repressão e controle sob o argumento de expulsar o tráfico de drogas e garantir segurança a seus moradores, como o caso da Unidade de Polícia Pacificadora instalada no Morro da Providência. A Praça Mauá, concebida como centro simbólico e catalisador do processo de revitalização, passou a abrigar ícones arquitetônicos direcionadas ao turismo, cultura e lazer: o Museu de Arte do Rio (2013) e o Museu do Amanhã (2015). A área da praça foi também reurbanizada após a demolição do viaduto da Perimetral (2014) e integrada à alameda Boulevard Olímpico (2016). E as construções da Via Binário e do sistema

\footnotetext{
13 Ficou então delegada à Cdurp a gestão de serviços públicos de competência municipal, como paisagismo, limpeza urbana, coleta de resíduos sólidos, drenagem de águas pluviais, iluminação pública, restauração e reconversão de imóveis, conservação de logradouros e de equipamentos urbanos e comunitários, dentre outros. Disponível em: http://bit.ly/2tXxo2Y. Acesso em 13 ago. 2017.
} 
de Veículo Leve sob Trilhos deslocaram o tráfego de automóveis para as ruas internas da região, possibilitando a fruição paisagística da orla da Baía de Guanabara e a valorização dos terrenos e armazéns que a margeavam.

Entre 2010 e 2016, período de vigência do duplo mandato do prefeito Eduardo Paes, algumas políticas patrimoniais realizadas na região receberam destaque nos discursos da Prefeitura. ${ }^{14} \mathrm{O}$ primeiro programa foi anunciado em 2010 com o objetivo de atuar no Morro da Conceição, através do restauro de algumas edificações tombadas pelo Iphan na década de 1930: Jardim do Valongo, Casa da Guarda, Mictório Público e Igreja da Prainha. Esse programa foi posteriormente desmembrado em dois: o dedicado à criação do Memorial do Cais do Valongo e do Circuito de Herança Africana (2011-2016) e o de restauro da Igreja da Prainha (2012-2015).

Outro investimento no patrimônio da região foi o Edital Pró-Sagas, programa viabilizado pela legislação do Porto Maravilha que previa que 3\% do valor arrecado com os Certificados do Potencial Adicional de Construção (Cepacs) ${ }^{15}$ seriam aplicados em ações voltados ao patrimônio material, imaterial e arqueológico. Voltado diretamente para os bens protegidos pelo Sagas, esse edital foi divulgado em agosto de 2013 pela Prefeitura e previu o auxílio financeiro para a reforma de oito sobrados, concedendo valores entre 200 mil e 400 mil reais provenientes de recursos do programa Porto Maravilha Cultural, iniciativa do Instituto Rio Patrimônio da Humanidade (IRPH) e da Cdurp ${ }^{16}$.

\footnotetext{
${ }^{14}$ As obras do Porto Maravilha foram amplamente divulgadas pela Prefeitura através de uma publicação trimestral, a revista Porto Maravilha, que contou com 22 edições entre os anos de 2010 e 2016. Disponível em: http://bit.ly/2Nokofk. Acesso em: 02 ago. 2017.

${ }^{15} \mathrm{O}$ instrumento do Cepac foi criado pelo Estatuto da Cidade visando possibilitar o financiamento de grandes obras previstas em Operações Urbanas, sem que o município precisasse utilizar recursos vinculados ao orçamento municipal, tendo sido regulado pela Instrução 401/03 da Comissão de Valores Mobiliários (Disponível em: http://bit.ly/2QNbEQm. Acesso em: 9 mar. 2019). No entanto, diversos pesquisadores têm feito críticas ao modelo, como Raquel Rolnik, que demonstrou que todos os Cepacs do Porto Maravilha foram comprados pela Caixa Econômica Federal com recursos do FGTS e, até agosto de 2017, o Fundo de Investimento Imobiliário da Caixa só havia colocado 8\% desses Cepacs adquiridos nos empreendimentos que estavam sendo construídos (ROLNIK, 2017).

${ }^{16}$ A seleção foi efetivada através do Processo Seletivo Público no 001/14, de apoio à Restauração do Patrimônio Cultural Imóvel, com utilização dos valores provenientes do Pró-APAC, conforme Decreto $n^{\circ}$ 33.879, de 5 de julho de 2012 (D.O.M. 17/01/2014). Os oito projetos contemplados pelo Pró-Sagas, possuíam uso comercial, com usos como bar, albergue temático, coletivo de empresas de design, café teatro e galeria de arte, entre outros (LIMA, 2014).
} 
Em um balanço das ações patrimoniais implementadas pelo Porto Maravilha, pode-se dizer que foram contemplados com investimentos público-privados alguns grupos sociais organizados, com destaque para o reconhecimento social da presença afro-brasileira na região e da memória da escravidão africana através da criação do Memorial do Cais do Valongo, medida que movimentou inúmeros conflitos e disputas na região ${ }^{17}$. Mas o que foi realizado nos demais bens protegidos pelo Sagas, que contabilizavam mais de mil imóveis, não recebeu publicidade. No universo amplo de ruas, vielas e sobrados portuários que haviam sido incluídos na área de preservação, realizei então um estudo na Rua Acre, que pertencia ao bairro portuário da Saúde. Meu interesse era entender como estavam sendo tratados esses espaços que, embora patrimonializados, não haviam sido alvos de ações extraordinárias de incentivo. $\mathrm{O}$ que tinha sido direcionado a eles foram ações rotineiras de gestão e controle de usos e materialidades. O outro lado da moeda do "patrimônio revitalizado".

\section{RUA ACRE: O PATRIMÔNIO CULTURAL COMO MECANISMO DE CONTROLE E GESTÃO DE USOS}

Apesar de possuir apenas 450 metros, a Rua Acre era importante por interligar três diferentes áreas da cidade: a de negócios (pelo encontro com a avenida Rio Branco), a de ocupação residencial das camadas populares (pela ligação com ruas da Saúde e do Centro) e a dedicada às atividades portuárias (por convergir na Praça Mauá). Era assim uma via de fronteiras, onde os paradoxos dos projetos urbanísticos e patrimoniais podiam ser observados em materialidades e usos híbridos. Seus sobrados em estilo colonial haviam

\footnotetext{
17 A construção do Memorial do Cais do Valongo foi o processo patrimonial que ganhou maior visibilidade social, gerando diversos estudos acadêmicos. Em março de 2011, pesquisas arqueológicas promovidas durante as obras do Porto Maravilha encontraram lajes de pedra e objetos do antigo cais, como búzios, miçangas, cachimbos, anéis e cristais, que passaram por ações de salvaguarda em conjunto com o Iphan. O Memorial do Cais do Valongo foi construído em 2012 e reconhecido em 2017 como Patrimônio da Humanidade pela Unesco. Em função da definição do escopo de análise, os diferentes aspectos dessa política patrimonial não serão desenvolvidos neste artigo. Sobre os agentes sociais e conflitos movimentados pela patrimonialização do cais, ver Guimarães (2014, 2016a) e Vassalo \& Cicalo (2015), entre outros.
} 
sido protegidos na década de 1980 pelo Sagas, mas a presença expressiva de edifícios construídos anteriormente à patrimonialização não faziam dali um conjunto arquitetônico homogêneo.

No lado ímpar da rua, que contornava o Morro da Conceição, todos os 40 imóveis eram incluídos na área protegida, mas apenas 23 eram casas assobradadas de dois andares que tinham recebido a classificação de "preservadas". Os demais imóveis eram "tutelados", inclusive prédios como o do Tribunal Regional da Justiça Federal, que era largo, verticalizado e de fachada espelhada. Já no lado par da rua ocorria o inverso, havia muitos prédios e poucos sobrados, demarcando visualmente a transição para o centro comercial da cidade. Apenas dois sobrados haviam sido "preservados" e sete imóveis estavam "tutelados", entre eles alguns prédios. Nesse lado, a metade da rua próxima à Praça Mauá estava fora de qualquer proteção patrimonial, incluindo nove imóveis.

Quando fotografei a rua em agosto de $2009^{18}$ (Figura 1), seus usos misturavam atividades comerciais, de serviços e habitacionais. Havia cerca de 70 estabelecimentos dedicados ao comércio varejista e frequentados durante os horários diurnos de trabalho por consumidores de perfil bastante heterogêneo. Diversas lojas serviam alimentação de baixo custo, como pastelarias, lanchonetes, botequins, restaurantes de "comida a quilo" e self-service. Uma das características visuais mais marcantes desses estabelecimentos era a divulgação de produtos em tabuletas expostas nas fachadas, que produziam um efeito colorido e tumultuado (Figura 3). Alguns sobrados também abrigavam hospedarias a preços populares ou "saunas e termas" com atividades de prostituição. Já os edifícios eram ocupados por salas comerciais e/ou pequenos apartamentos residenciais. No período noturno a rua apresentava pouco movimento, com bares abertos apenas na extremidade da Praça Mauá, onde se concentravam boates e casas com shows de striptease.

\footnotetext{
18 Entre setembro de 2007 e dezembro de 2009, realizei trabalho de campo no Morro da Conceição, bairro da Saúde, buscando compreender os conflitos sociais gerados direta ou indiretamente pelos projetos de "revitalização urbana" que estavam começando a ser implementados na região portuária. Em especial, pesquisei como diferentes habitantes articulavam discursos calcados na noção de patrimônio, com ênfase nos conflitos e disputas sociais envolvidos no reconhecimento da "Pequena África" (GUIMARÃES, 2011; 2014).
} 
Ao retornar à Rua Acre em dezembro de 2014 para reproduzir o clichê inicial das imagens e avaliar suas permanências e rupturas físicas e sociais ${ }^{19}$, sua vizinhança era outra. A Praça Mauá já estava radicalmente modificada por obras e mudanças de usos diretamente relacionadas às ações do Porto Maravilha. Com a construção dos grandes museus, foi intensificado o fluxo de turistas e visitantes de origens variadas, modificando as formas dos habitantes vivenciarem seus espaços, as noções de público e privado, bem como as maneiras de socializar. Outro imaginário emergiu, diferente do anterior que associava a praça à prostituição e à "bandidagem": ela tornou-se um espaço de "arte, lazer e cultura”. Os agentes do Estado que atuavam na praça também mudaram de perfil. Além do controle e repressão a "imigrantes, traficantes e prostitutas", guardas de trânsito, funcionários das secretarias de obras, de urbanismo, de turismo e de parques e jardins passaram a frequentar a área. Ou seja, uma nova ordem estética, moral e política se impôs em um breve espaço de tempo.

Nesses cinco anos transcorridos, contudo, os proprietários e locatários dos sobrados da Rua Acre não foram diretamente contemplados por qualquer edital de incentivo ao patrimônio nem a rua recebeu projetos de reurbanização. As transformações da rua ocorreram a partir de processos mais sutis e lentos de reconfiguração espacial e por isso permaneceram pouco visíveis. No retorno a campo para realizar as fotografias, as minhas aproximações junto aos comerciantes para perguntar sobre as reformas dos sobrados geraram imediata desconfiança. Eles temiam que eu fosse mais uma "fiscal da Prefeitura", explicitando o clima de tensão imposto pela concessionária responsável pela "revitalização" da região. Foi através da combinação de materiais coletados (reportagens jornalísticas, anúncios de venda e locação, breves conversas informais com os comerciantes, além da comparação fotográfica) que consegui perceber como o "valor patrimonial" da rua havia sido evocado para embasar

\footnotetext{
19 A inspiração para a utilização desse método de pesquisa de (re)fotografia havia surgido dos estudos de Ana Maria Galano (2000) sobre o Observatório Fotográfico de Paisagem, criado em 1991 pelo Ministério do Meio Ambiente francês. Para a realização da (re)fotografia contei com a parceria da arquiteta Mariana Moreth, que dividiu comigo o trabalho de percorrer todo o perímetro do Morro da Conceição. Para a catalogação dos registros fotográficos foi também importante o empenho de Juliana Menezes Pereira, bolsista de Iniciação Científica da Faperj (2015-2016).
} 
incursões sistemáticas de fiscalização, controle e sanções sobre a materialidade das fachadas dos imóveis.

No final de 2014, todos os comerciantes da Rua Acre haviam modificado a forma de exibir suas logomarcas, banners e adesivos que anunciavam produtos. Muitos também haviam pintado as fachadas dos imóveis, seguindo orientações de cor dos órgãos patrimoniais (Figura 2). Dessa forma, ocorreu uma gradual limpeza visual da rua. Segundo comerciantes, foram agentes da Prefeitura que proibiram a colocação de tabuletas, exigiram a padronização dos formatos das logomarcas e obrigaram a retirada de marquises, aplicando multas nos que não seguissem as novas regras urbanísticas. Ou seja, regras e normas foram impostas aos comerciantes, que compulsoriamente realizaram adaptações nos imóveis (Figura 4). Ainda que tenha escutado relatos de pequenas e cotidianas formas de resistir aos fiscais operando nas margens das normas, como a insistência em manter tabuleta não na fachada, mas apoiada de forma portátil na calçada.

\section{Figura 1: em agosto de 2009, tabuletas estão afixadas do lado de fora do} estabelecimento.

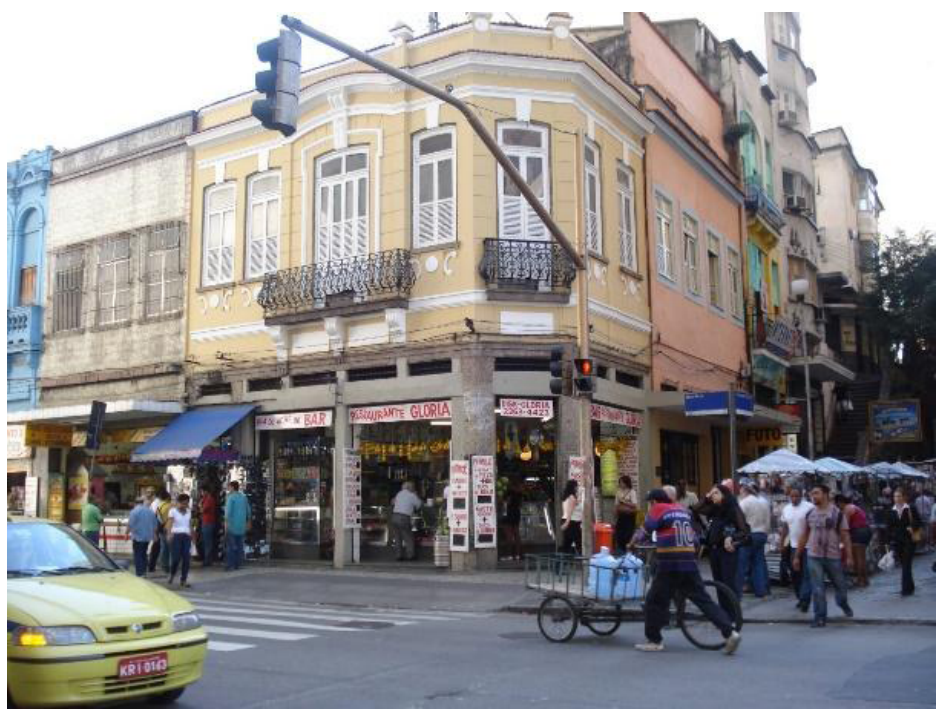

Fonte: foto da autora. 
Figura 2: em dezembro de 2014, o imóvel foi pintado, recebeu toldos e houve a retirada de tabuletas da fachada.

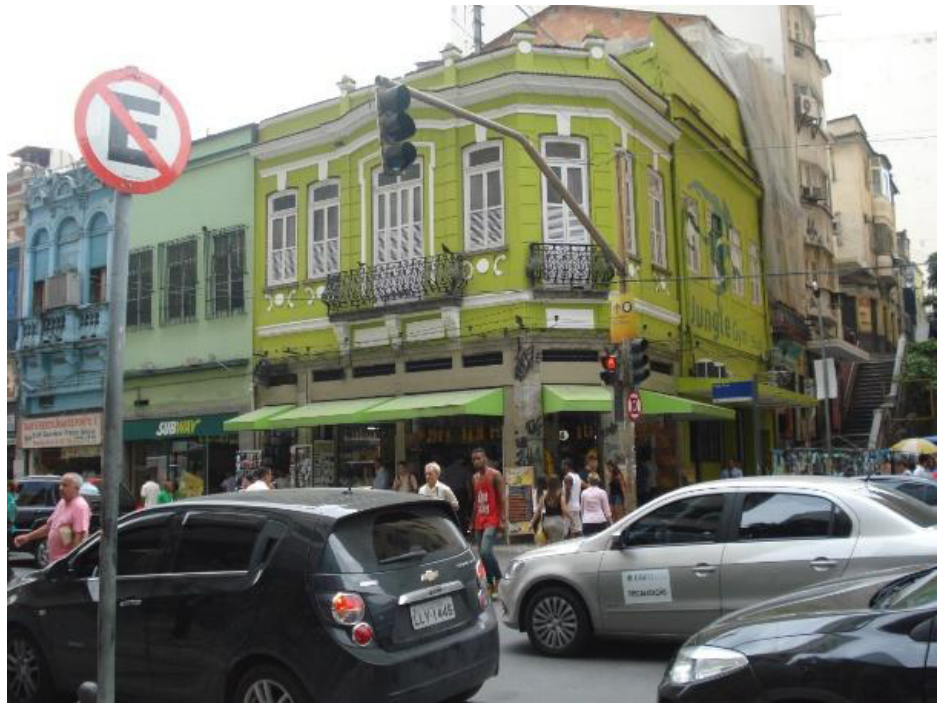

Fonte: foto da autora.

Figura 3: em agosto de 2009, pastelaria com tabuletas coloridas e portas abertas.

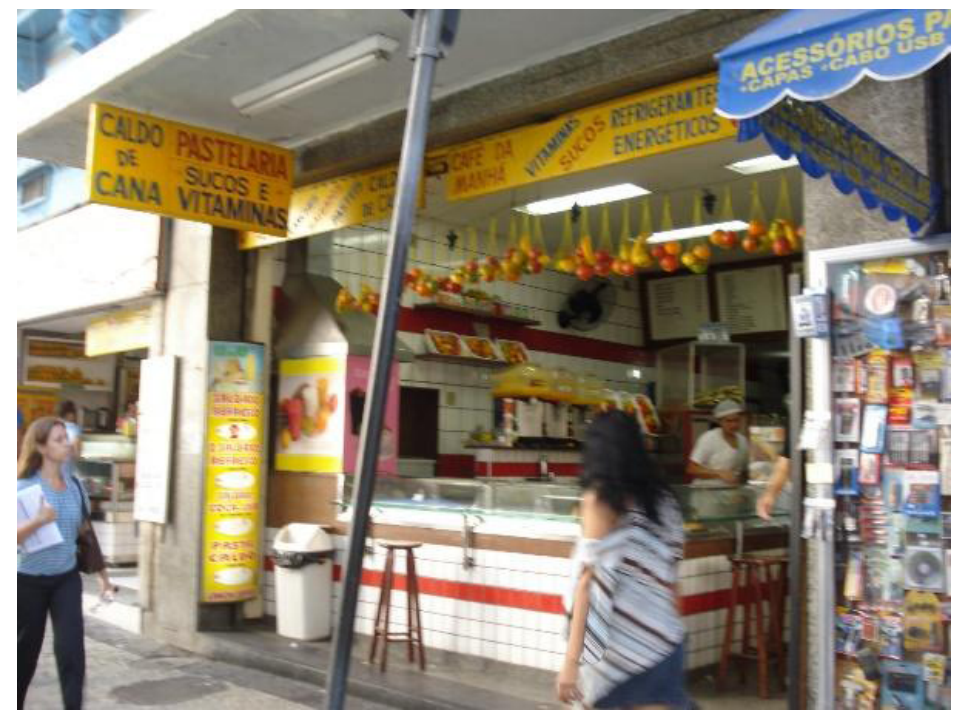

Fonte: foto da autora. 
Figura 4: em dezembro de 2014, o mesmo sobrado se transformou em loja de fast-food com ambiente climatizado.

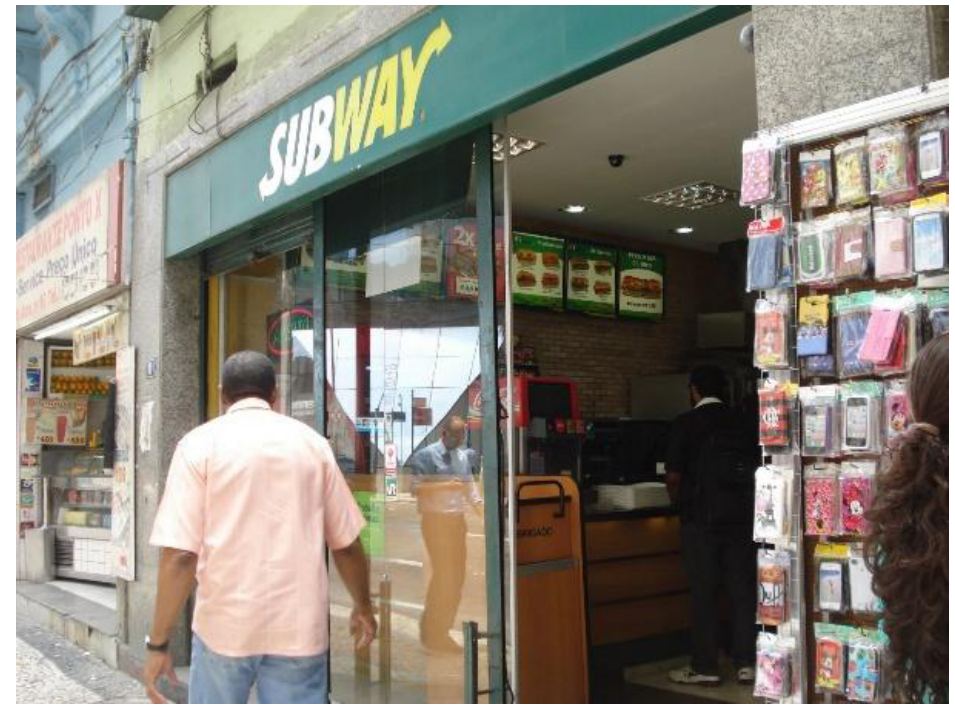

Fonte: foto da autora.

Entre os estabelecimentos localizados em sobrados preservados pelo Sagas, nove mudaram de uso e sete fecharam as portas, especialmente as lojas pequenas e voltadas para o comércio local, como uma loja de materiais de limpeza, uma confeitaria, uma loja de CDs e outra de equipamentos eletrônicos semiusados (Figuras 5 e 6). O aumento do número de imóveis fechados pode ter sido reflexo das instabilidades econômicas que, entre outros eventos, envolveu a denúncia de irregularidades nas transações das grandes construtoras nacionais, paralisando várias obras da iniciativa privada na região. A supervalorização dos imóveis da área não teria, assim, acompanhado a demanda de sua ocupação por novos empreendimentos, causando um efeito reverso, que foi o esvaziamento das atividades ${ }^{20}$.

\footnotetext{
${ }^{20}$ Para qualificar melhor as dinâmicas comerciais da Rua Acre, seria necessário um trabalho de campo complementar que pesquisasse também as motivações que levaram os comerciantes a fecharem suas lojas. Contudo, no contexto de produção do Porto Maravilha a realização de entrevistas com os comerciantes estava bastante dificultada pelo constante medo de que suas atividades fossem classificadas como ilegais ou irregulares. Uma ponderação possível é que algumas das mudanças vistas no comércio podem ter outras causas não diretamente relacionadas à revitalização urbana, como a revisão de projeto familiar ou profissional ou mesmo o falecimento de proprietário.
} 
Figura 5: em agosto de 2009, loja de equipamentos eletrônicos em funcionamento.

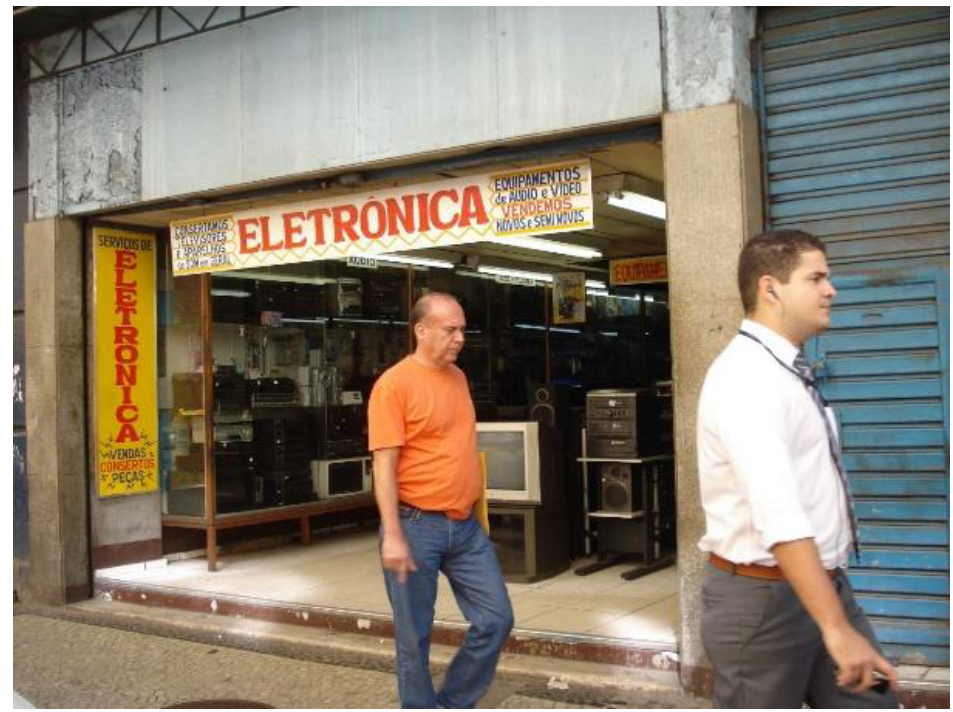

Fonte: foto da autora.

Figura 6: em dezembro de 2014, o mesmo sobrado de portas fechadas.

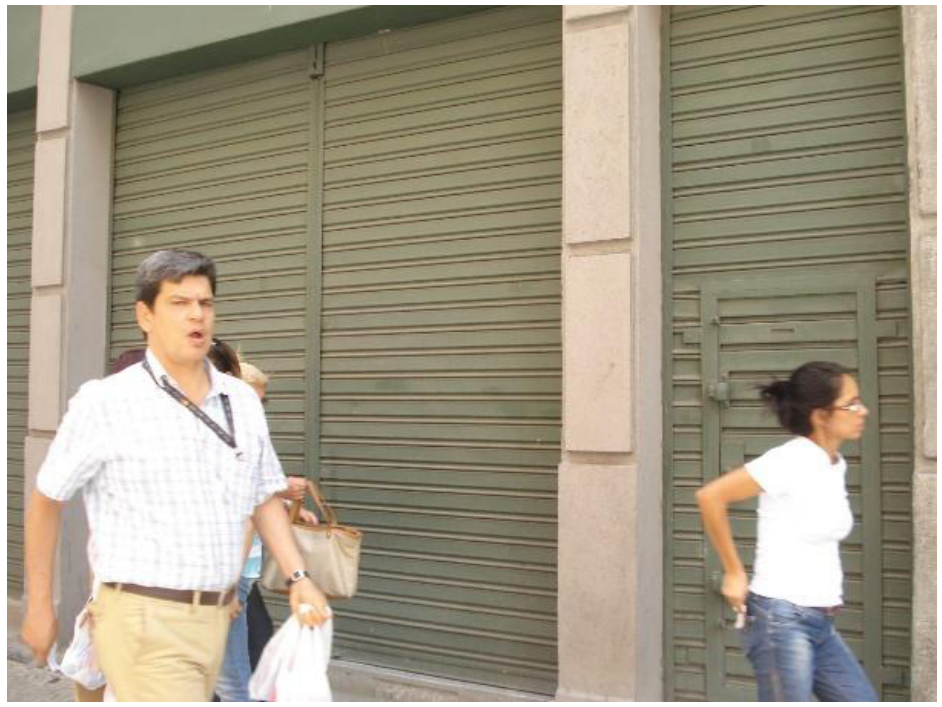

Fonte: foto da autora. 
Na parte tutelada, onde as lojas comerciais ficavam no andar térreo de edifícios, as mudanças foram em menor proporção em relação à parte dos sobrados, os comerciantes tiveram que fazer apenas pequenas adequações em suas formas de anunciar produtos e logomarcas. Nenhuma loja fechou as portas e apenas três mudaram de uso: dois restaurantes novos abriram, sendo um mais elitizado, tomando lugar de um bar e uma livraria; e um mercado ocupou o antigo espaço de uma loja de iluminação. A diferença de número de estabelecimentos fechados ou modificados na parte preservada e tutelada sugere que houve mais pressão sobre a conservação e manutenção dos sobrados preservados do que nas lojas térreas de edifícios, com comerciantes não conseguindo arcar com os custos das reformas exigidas para a "adequação" dos imóveis (Figuras 7 e 8).

Figura 7: em agosto de 2009, papelaria e bares ocupam as lojas térreas de um edifício.

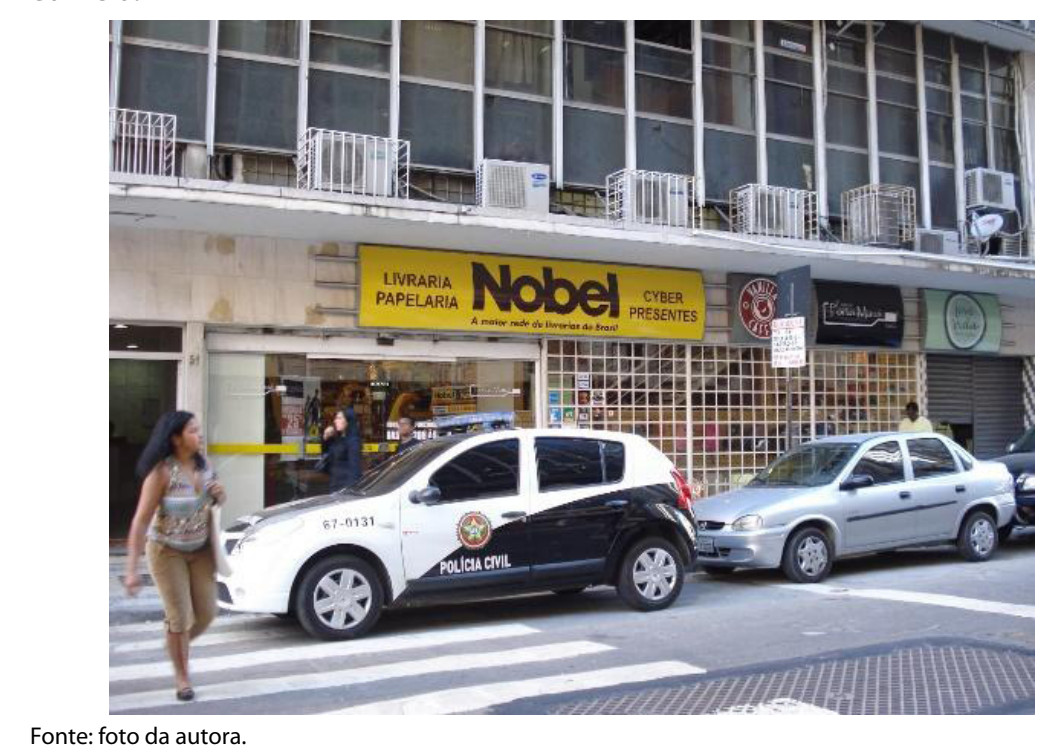

Fonte: foto da autora. 


\section{Figura 8: em dezembro de 2014, as lojas são ocupadas por um único res-} taurante.

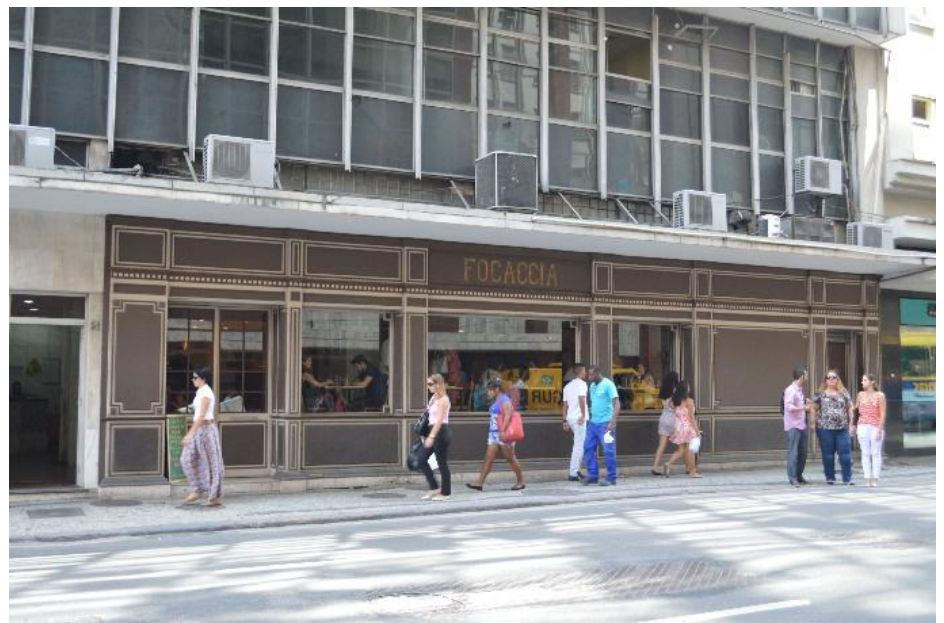

Fonte: foto por Mariana Moreth.

No entanto, o trecho da rua que não era protegido pelo Sagas foi que se transformou de forma mais impactante. Dos dez pontos de lojas, entre 2009 e 2014 metade mudou de uso e buscou atender a um público de maior poder aquisitivo, quatro voltando-se especificamente para atividades alimentícias e uma para a venda de roupas femininas. Antes, havia uma loja de venda de móveis de escritório, uma de jogos eletrônicos e fliperamas, uma filial do Correios e um sobrado de portas fechadas. Quatro desses novos estabelecimentos eram lojas térreas do Edifício Jequitibá, o que indica possível mudança dos preços de aluguel praticados pelo condomínio. Seguindo também as normas urbanísticas e patrimoniais impostas no período, o edifício retirou toda sua marquise, fazendo com que algumas lojas instalassem toldos para proteção do sol e chuva.

O caso mais notório de transformação material da rua foi a construção do Porto Brasilis, edifício coorporativo de 19 andares cuja entrada principal ficava na rua São Bento, mas a lateral ocupava quase todo um quarteirão da Rua Acre. Projetado em 2008, o espaço abrigou por meses um canteiro de obras até o edifício ser inaugurado em março de $2012^{21}$. Primeiro empreendi-

\footnotetext{
${ }^{21}$ O projeto do prédio havia sido desenvolvido em associação com o Fundo Americano e adquirido integralmente
} em 2010 pela Petros-Fundação Petrobras de Seguridade Social, fundo de pensão dos funcionários da petrolífera. 
mento coorporativo realizado durante a revitalização da região, sua fachada espelhada e de grandes dimensões produziu um ícone arquitetônico atrelado diretamente ao setor empresarial, despontando como referência de escritórios de grandes empresas da cidade, como da japonesa Nissan Figuras 9 e 10).

Figura 9: em agosto de 2009, canteiro de obras do edifício Porto Brasilis.

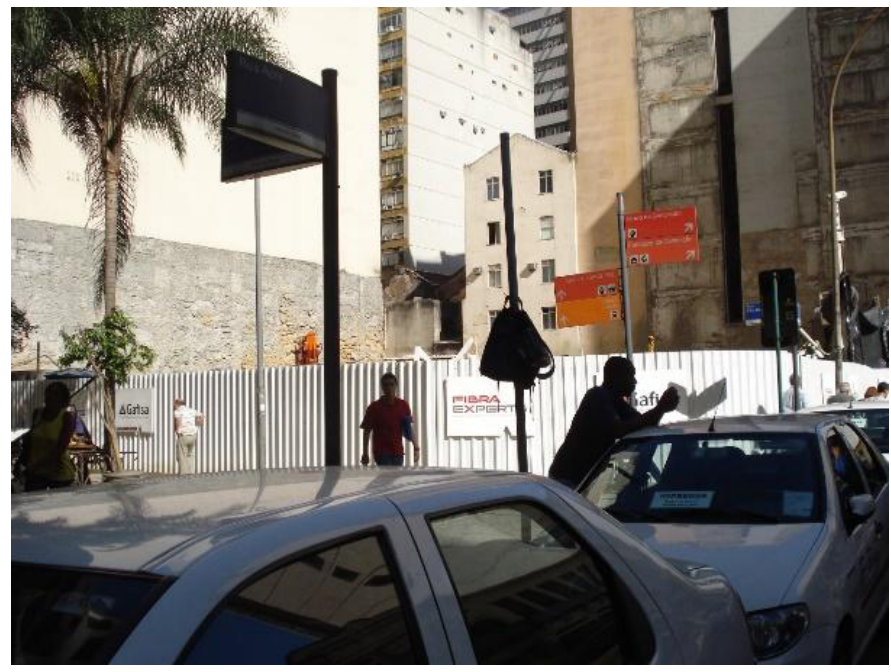

Fonte: foto da autora.

Figura 10: em dezembro de 2014, edifício inaugurado e ocupado por escritórios.

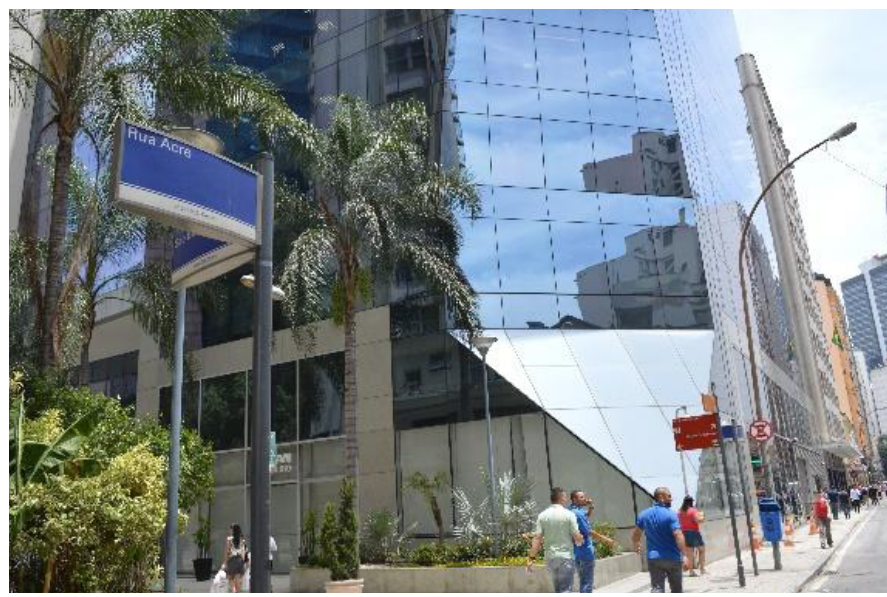

Fonte: foto por Mariana Moreth. 
De acordo com Fernando Kenworthy, chefe executivo da Fibra Experts, grupo responsável pela construção do empreendimento, sua localização foi escolhida por ser o encontro da Avenida Rio Branco com a Praça Mauá "uma espécie de marco zero do projeto de requalificação da Região Portuária" (PRIMEIRO, 2012). Seu discurso enfatizava as vantagens para a região de ter um prédio com "excelente arquitetura e de forma sustentável" (PRIMEIRO, 2012), o que significava na prática que ele tinha sido projetado para racionalizar o consumo de água e energia. Tal economia fez com que o projeto do prédio recebesse o "USGBC/US Green Building Council (EUA) certificação internacional de Green Building/Leed, na categoria Gold” (PRIMEIRO, 2012), título pomposo que legitimava suas qualidades ditas ecológicas e fazia que o prédio fosse apresentado pelo chefe executivo como contraposto aos "muitos edifícios obsoletos em tecnologia" (PRIMEIRO, 2012) que ocupavam a região portuária e o Centro do Rio.

Quase um ano depois de inaugurado, uma reportagem do jornal O Globo também explorava a mesma noção de "sustentabilidade" do prédio através de sua "tecnologia verde". Contrastava então os tempos arquitetônicos que ele tinha provocado na região, fazendo "o passado e o presente viverem lado a lado” em sobrados construídos até 1930, edifícios art déco, edifícios modernos ou pós-modernos.

Nesse pedaço do Centro - encravado numa das regiões da cidade que mais vem sofrendo transformações nos últimos dois anos -, o passado e o presente vivem lado a lado. Ou em calçadas opostas. São sobrados de inspiração portuguesa do século XIX, que se refletem na fachada espelhada de um prédio pós-moderno, que é vizinho de uma construção remanescente da abertura da Avenida Central, que tem o mesmo CEP de alguns prédios em estilo art déco... Um museu de arquitetura a céu aberto que pode ser percorrido em poucos passos (CANDIDA, 2013).

Os sobrados e prédios que ficaram no entorno do Porto Brasilis passaram assim a atuar como uma espécie de fundo paisagístico, que possibilitou que esse ícone do progresso e do mercado se sobressaísse como figura. Sua mensagem reafirmava a mudança de centralidade do poder, agora concentrado 
nas mãos das empresas privadas que atuavam na região via Cdurp. A história então retomada no jornal através dos antigos sobrados era um gatilho discursivo para a exaltação dos ideais de progresso e modernidade. Na construção das cidades globais, tecnologias e certificados de "sustentabilidade" legitimavam a estética empresarial. Nas transformações urbanísticas da região portuária, as ações rotineiras de ordenamento e controle e a celebração excepcional de "novas tecnologias" agiram, portanto, como mecanismos de conciliação entre as ideias de "tradição" e "modernidade" portadas pelas políticas do "patrimônio revitalizado".

\section{O EFEITO DE REVITALIZAÇÃO DOS “AMBIENTES CULTURAIS"}

Como ocorrido em outras áreas portuárias do mundo classificadas como patrimônios culturais e/ou sítios históricos, ao longo de quatro décadas de contínuas intervenções os espaços portuários cariocas foram ressignificados, atraindo jovens de classe média, artistas plásticos, organizações não governamentais (ONGs), associações recreativas e culturais, bares, casas de shows e edifícios corporativos. Seus habitantes também tiveram suas formas de organização social alteradas, com os ritmos e as extensões da transformação sendo ditados tanto pelos novos fluxos urbanos quanto pela proliferação de conflitos e variadas formas de adesão, resistência e subversão às intervenções ${ }^{22}$.

Contudo, processos sociais que não foram protagonizados por nenhum grupo politicamente organizado ficaram pouco visibilizados, mesmo moldando de forma profunda as formas subjetivas dos habitantes da região vivenciarem

\footnotetext{
${ }^{22}$ No jogo de rupturas e continuidades com as experiências de passado e os projetos de futuro, alguns propuseram, por exemplo, formas de luta pela moradia popular (GUTTERRES, 2014) ou da ocupação de prédios governamentais desativados (BIRMAN; FERNANDES; PIEROBON, 2014). Novos habitantes também tiveram suas atividades constrangidas por moradores e movimentos sociais que os acusavam de elitizar a região, como no caso dos artistas plásticos que instalaram ateliês em antigas fábricas como a Bhering (BORDENAVE, 2014). Entre movimentos sociais que se identificaram como portadores da cultura e da memória afro-brasileiras da região, a narrativa da Pequena África atendeu a diferentes expectativas e demandas, como o pleito étnico-territorial do Quilombo da Pedra do Sal (GUIMARÃES, 2013; 2015) e a demanda por uma sede de ensaios do bloco carnavalesco Afoxé Filhos de Gandhi (GUIMARÃES, 2016b).
} 
as transformações da região. Foi buscando compreender esses processos sutis que observei a Rua Acre. Nela, houve uma contínua reorganização das fronteiras simbólicas e territoriais em nome do patrimônio cultural, mesmo que não calcado em grandes narrativas nacionais ou identitárias. Ali, a atuação do patrimônio se deu vinculada a rotineiras formas de gestão que, baseadas na autoridade e legitimidade estatal, controlaram e coibiram antigas práticas e usos do comércio popular que passaram a ser considerados "ilegais", bem como incentivaram intervenções estéticas e ocupações comerciais "modernizadoras".

Localizada no entorno de grandiosos projetos patrimoniais e urbanísticos, a Rua Acre foi gerida com a finalidade de garantir sua "ambiência cultural", servindo como materialidades coadjuvantes para que outras materialidades se destacassem como autênticos símbolos de tradição ou modernidade. O apagamento público desse tipo de rua tinha, assim, uma função dialética, que era fazer fundo paisagístico para que outros espaços e práticas pudessem sobressair e se legitimar na malha urbana.

Assim, da mesma maneira que alguns espaços foram entendidos como cultural, histórica ou arquitetonicamente relevantes, outros que compuseram os chamados ambientes urbanos da região portuária também foram socialmente construídos. Sua (des)importância foi igualmente sustentada por práticas discursivas e relações de poder que determinaram, no processo relacional de valorização/desvalorização de bens, práticas e habitantes, quais eram raros ou vulgares, quais deveriam ser preservados ou eram passíveis de disponibilização para troca, venda ou extinção.

A partir da observação das ações impetradas na região portuária desde a década de 1980 e das recentes transformações da Rua Acre foi possível observar como os discursos sobre os "desvios" ou "maus usos" do patrimônio histórico edificado das regiões empobrecidas são correntemente associados pelos planejadores urbanos a "problemas de depredação" ou da "falta de conservação". Contudo, tais discursos muitas vezes são vinculados ao aumento da presença do Estado nessas regiões em processo de revitalização, através de ações tanto excepcionais quanto rotineiras de produção, fiscalização e controle dos espaços. No âmbito das políticas governamentais, portanto, a conjugação de ações 
patrimoniais com ações de revitalização se tornou um dos meios de gerir o que Foucault denominou de problemas de posicionamento: "o problema de saber que relações de vizinhança, que tipo de estocagem, de circulação, de localização, de classificação dos elementos humanos devem ser mantidos de preferência em tal ou tal situação para chegar a tal ou tal fim" (FOUCAULT, 2001, p. 413).

\section{REFERÊNCIAS BIBLIOGRÁFICAS}

1. BARANDIER, Henrique. Projeto urbano no Rio de Janeiro e as propostas para a área central nos anos 1990. In: SILVA, Rachel Coutinho da (org.). A cidade pelo avesso: desafios do urbanismo contemporâneo. Rio de Janeiro: Viana \& Mosley: PROURB, 2006. p. 145-167.

2. BOURDIEU, Pierre. Sobre o Estado. São Paulo: Companhia das Letras, 2012.

3. BIRMAN, Patrícia; FERNANDES, Adriana; PIEROBON, Camila. Um emaranhado de casos: Tráfico de drogas, estado e precariedade em moradias populares. Mana, Rio de Janeiro, v. 20, n. 3, p. 209-226, 2014.

4. BORDENAVE, Geisa. A antiga fábrica da Bhering: novos usos do espaço e manifestações artísticas na zona portuária do Rio de Janeiro. 2014. Dissertação (Mestrado em Ciências Sociais) - Universidade do Estado do Rio de Janeiro, Rio de Janeiro, 2014.

5. CANDIDA, Simone. A mistura de estilos que faz do Centro um museu de arquitetura. O Globo, Rio de Janeiro, 24 fev. 2013. Caderno Rio. Disponível em: https://glo.bo/2uNrIt7. Acesso em: 24 jul. 2017.

6. CARLOS, Cláudio Antônio. Áreas de proteção do ambiente cultural (Apac): da idealização à banalização do patrimônio cultural carioca. 2008. Tese (Doutorado em Urbanismo) - Universidade Federal do Rio de Janeiro, Rio de Janeiro, 2008.

7. CARVALHO, José Murilo. Os bestializados: o Rio de Janeiro e a República que não foi. São Paulo: Companhia das Letras, 2001.

8. CERTEAU, Michel de. A invenção do cotidiano. Rio de Janeiro: Vozes, 2011.

9. CHALHOUB, Sidney. Cidade febril: cortiços e epidemias na Corte Imperial. São Paulo: Companhia das Letras, 1996.

10. COMPANS, Rose. Parceria público-privado na renovação urbana da zona portuária do Rio de Janeiro. Cadernos IPPUR, Rio de Janeiro, ano XII, n. 1, p. 79-105, 1998. 
11. FONSECA, Maria Cecília Londres. O patrimônio em processo: trajetória da política federal de preservação no Brasil. Rio de Janeiro: Editora UFRJ: Iphan, 2005.

12. FOUCAULT, Michel. Ditos e Escritos. Rio de Janeiro: Forense, 2001. (v. III)

13. GALANO, Ana Maria. Entre nostalgias e sinais de uma nova estética: observatórios fotográficos das paisagens na França. Cadernos de Antropologia e Imagem. Rio de Janeiro, v. 10, p. 83-102, 2000.

14. GONÇALVES, José Reginaldo. A retórica da perda: os discursos do patrimônio cultural no Brasil. Rio de Janeiro: Editora UFRJ: Iphan, 1996.

15. GORELICK, Adrián. Das vanguardas a Brasília: cultura urbana e arquitetura na América Latina. Belo Horizonte: Editora UFMG, 2005.

16. GUIMARÃES, Roberta Sampaio. A utopia da Pequena África: os espaços do patrimônio na zona portuária carioca. 2011. Tese (Doutorado em Sociologia e Antropologia) - Universidade Federal do Rio de Janeiro, Rio de Janeiro, 2011

17. GUIMARÃES, Roberta Sampaio. Urban interventions, memories and conflicts: black heritage and the revitalization of Rio de Janeiro's port zone. Vibrant, Brasília, n. 10 , p. 208-227, 2013

18. GUIMARÃES, Roberta Sampaio. A utopia da Pequena África: projetos urbanísticos, patrimônios e conflitos na zona portuária carioca. Rio de Janeiro: Editora FGV, 2014.

19. GUIMARÃES, Roberta Sampaio. A arquitetura de um espaço franciscano em tempos de reurbanização do porto carioca. Religião e Sociedade, Rio de Janeiro, v. 35, n. 1, p. 87-106, 2015.

20. GUIMARÃES, Roberta Sampaio. Entre memorias de Portugal y de África: las políticas patrimoniales en la región portuaria de Rio de Janeiro, Brasil. Cuadernos de Antropología Social, Buenos Aires, v. 44, p. 51-66, $2016 \mathrm{a}$.

21. GUIMARÃES, Roberta Sampaio. Patrimônios e conflitos de um afoxé na reurbanização da região portuária carioca. Mana, Rio de Janeiro, v. 22, n. 2, p. 311-340, 2016b.

22. GUTTERRES, Anelise dos Santos. A resiliência enquanto experiência de dignidade: antropologia das práticas políticas em um cotidiano de lutas e contestações junto a moradoras ameaçadas de remoção nas cidades sede da Copa do Mundo 2014 (Porto Alegre, RS e Rio de Janeiro, RJ). Tese (Doutorado em Antropologia Social), Universidade Federal do Rio Grande do Sul, Porto Alegre, 2014.

23. HOLSTON, James. A cidade modernista: uma crítica de Brasília e sua utopia, São Paulo: Companhia das Letras, 1993. 
24. JACOBS, Jane. Morte e vida de grandes cidades. São Paulo: Martins Fontes, 2007.

25. LEITE, Márcia Pereira. Da metáfora da guerra à mobilização pela paz: temas e imagens do Reage Rio. Cadernos de Antropologia e Imagem, Rio de Janeiro, v. 4, p. 121-145, 1995.

26. LIMA, Raphael. Mais 15 imóveis serão restaurados com o apoio da prefeitura do Rio: Sete sobrados no Centro Histórico e outros oito imóveis localizados na Região Portuária serão beneficiados pelo Programa de Apoio à Conservação do Patrimônio Cultural. IRPH-PRJ. Rio de Janeiro, 30 jun. 2014. Disponível em: http://bit.ly/2Rn6U3c. Acesso em: 14 jan. 2019.

27. NAZARETH, Alexandre Mendes. Editorial. Cadernos do Patrimônio Cultural, Rio de Janeiro, n. 4, p. 63-67, 1994.

28. OLIVEIRA, João Pacheco de. Pacificação e tutela militar na gestão de populações e territórios. Mana, Rio de Janeiro, v. 20, n. 1, p. 125-161, 2014.

29. PIO, Leopoldo Guilherme. Cidade como patrimônio: Revitalização e preservação no centro histórico do Rio de Janeiro. 2001. Dissertação (Mestrado em Ciências Sociais) - Universidade Federal do Rio de Janeiro, Rio de Janeiro, 2001

30. PRIMEIRO novo empreendimento corporativo é inaugurado na região do porto Maravilha. Porto Maravilha, Rio de Janeiro, 4 maio 2012, Notícias, Obras. Disponível em: http://bit.ly/2QOV2Yr. Acesso em: 4 ago. 2017

31. PREFEITURA DA CIDADE DO RIO DE JANEIRO. Guia das APACs. SAGAS (Saúde, Gamboa e Santo Cristo) e entorno do mosteiro de São Bento. Rio de Janeiro: PCRJ/IRPH, Ano II, n. 1, 2012.

32. ROLNIK, Raquel. Prefeitura do Rio proíbe novos tombamentos na região do Porto Maravilha. Blog da Raquel Rolnik. São Paulo, 11 ago. 2017. Disponível em: http:// bit.ly/2RbvQdQ. Acesso em: 16 ago. 2017.

33. SARUE, Betina. Os capitais urbanos do Porto Maravilha. Novos Estudos CEBRAP, São Paulo, v. 35, n. 2, p. 79-97, 2016.

34. VASSALO, Simone; CICALO, André. Por onde os africanos chegaram: o cais do Valongo e a institucionalização da memória do tráfico negreiro na região portuária carioca. Horizontes Antropológicos, Porto Alegre, ano 21, n. 43, p. 239-271, 2015.

35. WEINER, Annette. Inalienable possessions: the paradox of keeping while giving. Berkeley: University of California Press, 1992. 